\title{
Health related quality of life in adolescents with idiopathic scoliosis: a cross-cultural comparison between two methods of treatment
}

\author{
E D'agata ${ }^{1 *}$, C Pérez-Testor ${ }^{1}$, M Rigo $^{2}$, S Negrini ${ }^{3}$, V Cigoli ${ }^{4}$ \\ From 8th International Conference on Conservative Management of Spinal Deformities and SOSORT 2011 \\ Annual Meeting \\ Barcelona, Spain. 19-21 May 2011
}

\section{Purpose}

The present study aims at evaluating the effects produced on HRQOL by two different methods of physiotherapy in adolescent population with Idiopathic Scoliosis (IS): SEAS, used in Milan (Italia) in ISICO center, and Barcelona Scoliosis Physical Therapy School, in E. Salvá Institut (Spain).

\section{Background}

Studies related to HRQOL are generally few [1], controversial and besides there is a lack of research related to physiotherapy and HRQOL [2].

\section{Materials and methods}

Twenty-one subjects took part to the study, ages ranging between 9 and 18 years. Thirteen of them were Italian (5 boys and 8 girls) and the 9 Spanish (2 boys and 7 girls). For all of them it was the first time to be visited. The materials used were: Rosenberg's self-esteem test [3,4], Self Concept test [5], Body Satisfaction Scale [6] and SRS-22 questionnaire $[7,8]$. Tests were given three times: on the first visit, three and six months later.

\section{Results}

Through a mixed ANCOVA, we found statistical differences between pre-test and post-test. In relation to the interaction effect, Time X Treatment, the Italian group improved in SRS-Pain while the E.Salvá group presented worse results at the end. However, the treatment had a significative effect on SRS-Self Image $(\mathrm{p}=0.016)$ and on Emotional Self Concept, as the E.Salvá group scored higher.

\section{Conclusions}

Further researches will aim at increasing the sample size, in order to enrich the results, and at looking for more homogenous groups and centers (Country, setting, size, etc).

\section{Author details}

'Universitat Ramon Llull, Barcelona, Spain. ${ }^{2}$ Institut Elena Salvá, Barcelona, Spain. ${ }^{3}$ ISICO, Milan, Italy. ${ }^{4}$ Università Cattolica di Milano, Milan, Italy.

Published: 27 January 2012

\section{References}

1. Levitskiy A, Yaroslavska S, Chekryzhev D, Rychlevskiy K, Pliatsek V, Velikiy O, Bebeshko O: Influence of motion activity on psycho emotional status of scoliotic patients treated with brace. Scoliosis 2010, 5:065.

2. Weiss HR, Cherdron J: Effects of Schroth's rehabilitation program on the self concept of scoliosis patients. Rehabilitation 1994, 33(1):31-4.

3. Martín-Albo J, Núñez J, Navarro JG, Grijalvo F: The Rosenberg Self-Esteem Scale: translation and validation in University students. The Spanish Journal of Psychology 2007, 10(2):458-467.

4. Prezza M, Trombaccia F, Armento L: La scala dell'autostima di Rosenberg: traduzione e validazione italiana. Bollettino di psicologia applicata 1997, 223:35-44.

5. García F, Musitu G: AF5. Autoconcepto forma 5. Madrid: Tea ediciones; 2009.

6. Gismero E: Habilidades sociales y anorexia nerviosa. Madrid: Universidad Comillas; 1996

7. Climent JM, Bagó J, Sánchez J, et al: Validity of the Spanish version of the Scoliosis Reseacrh Society -22 (SRS-22) Patient Questionnaire. Spine 2005, 30:705-709.

8. Monticone M, Baiardi P, Calabrò D, Calabrò F, Forti C: Development of the Italian version of the revised Scoliosis Reseacrh Society-22 Patient Questionnaire, SRS-22r-l: cross-cultural adaptation, factor analysis, reliability, and validity. Spine 2010, 35(24):E1412-1417.

doi:10.1186/1748-7161-7-S1-O6

Cite this article as: D'agata et al:: Health related quality of life in adolescents with idiopathic scoliosis: a cross-cultural comparison between two methods of treatment. Scoliosis 2012 7(Suppl 1):O6.

${ }^{1}$ Universitat Ramon Llull, Barcelona, Spain

Full list of author information is available at the end of the article

(c) 2012 D'agata et al; licensee BioMed Central Ltd. This is an open access article distributed under the terms of the Creative Commons 